\title{
"In Our Culture, Poets Have More Power than Politicians": The Lives, Deaths and Legacies of Cheb Hasni and Lounès Matoub
}

\section{Stephen Wilford}

City University London

stephen.wilford.1@city.ac.uk

\begin{abstract}
This article examines the lives, deaths and legacies of two of the most popular Algerian musicians of the 1990s: "Cheb" Hasni Chakroun and Lounès Matoub. Both were killed at the height of their fame, as a result of the violence produced by the socio-political unrest and civil war in their country. Here, the ways in which these musicians engaged with political discourses are addressed, as well as the controversies that surrounded their subsequent killings. Furthermore, there is a consideration of their ensuing mythologization and place within collective memories of 1990s Algeria, as respected popular musicians, as cultural martyrs and as victims of circumstance. Finally, an assessment is made of their legacies within enduring discourses of political conspiracy, showing how the suspicions of Algerians with regards to their killings enable engagement with contemporary Algerian politics.
\end{abstract}

KEYWORDS: Algeria, Kabylia, Cheb Hasni, Lounès Matoub, memory, conspiracy theories

\section{Introduction}

On 22 June 1961, at the height of the Algerian war of independence, the revered singer "cheikh" Raymond Leiris was shot and killed in the market of Constantine, a city in the east of Algeria. Whilst his killers were never brought to justice, his death illustrated both the violence of this period of Algerian history and the 
dangers faced by the country's well-known musicians. His murder was also one of the catalysts for the mass emigration of Algerian Jews after national independence in 1962 (Evans 2012b: 10-16). The ensuing two decades were relatively peaceful for Algeria, as the country established itself as a powerful, wealthy independent nation. During this time, Algerians could surely not have envisaged that violence would return to, and socially and politically fracture, their country in the 1980s and 1990s. Throughout this period, popular musicians found themselves in positions of both power and peril, equipped to voice the indignation of ordinary Algerians at a range of domestic socio-political issues, but facing ostracism and intimidation from the authorities and an increasingly violent Islamist opposition (Morgan 2004: 126). The censorship initially faced by musicians was slowly replaced by threats of violence, and culminated with the killings of musicians, artists and other public figures, whose widespread popularity failed to protect them when their views did not correspond with those on either side of Algeria's political divide.

This article examines the lives, deaths and enduring legacies of two of Algeria's most celebrated popular musicians: "Cheb" Hasni Chakroun (1968-1994) and Lounès Matoub (1956-1998). Both musicians were killed whilst at the height of their musical careers, and as a direct result of the violence sweeping their country in the 1990s. Each has been posthumously positioned as a martyr, albeit in distinct and contrasting ways. Their deaths have come to be viewed by Algerians as symbolic of the political and social turmoil that fractured Algerian society over a twenty-year period, and to signify the broader public influence of musicians within Algeria.

The stories of Hasni and Matoub are characterised by both similarity and difference. Their musical careers overlapped with one another, and at the times of their respective deaths, they were considered amongst the most celebrated musicians in Algeria. Their musics and legacies have subsequently become synonymous with the violence of 1990s Algeria. Yet there are also notable differences, not least in the contrast between their musical styles. Hasni was a raï singer who commented upon the frustrations experienced by Algerians at the time, but rarely engaged directly with politics within his lyrics. Matoub, in contrast, performed music that drew upon various styles, including chaabi and Berber folk musics, and was a strikingly outspoken artist, whose criticisms could not have been more explicit. Whilst Hasni was focused upon the concerns of the Algerian youth, Matoub's work was devoted primarily to the plight of the country's Berber population, particularly in the region of Kabylia, and the efforts to gain recognition for Berber history and culture.

This article is therefore concerned with issues of music, censorship, violence and death within the specific context of 1990s Algeria, and highlights the important role played by popular musicians in opening upon political discourse to the Algerian people. The cases of Hasni and Matoub are the result of particular cultural and political conditions in Algeria at this time, and this work contributes to a body of literature that examines the extended periods of violence that Algeria has experienced over the past fifty years. Whilst issues of death and violence are central to this article, I am also mindful of the work of James McDougall (2005), who warns against the dangers of promoting a historical discourse of circular, reoccurring violence and savagery, which might essentialize conflict as somehow 
integral to the Algerian character. Instead, I am interested in considering how historical conditions produced circumstances in which these musicians were assassinated, and how their deaths have subsequently played a role in collective memories of 1990s Algeria, whilst continuing to feed into contemporary sociopolitical engagement and political suspicion amongst Algerians.

Although the lives and deaths of Hasni and Matoub were the result of a specifically Algerian context, their stories also share certain parallels with those of musicians in other cultures. The Afghan singer Ahmad Zahir, for example, was an idolised popular musician whose lyrics criticised the government, and who died in controversial circumstances in 1979. Zahir's death, like that of Hasni and Matoub, led to widespread mourning, and he has subsequently been positioned as a mythologised martyr by Afghan listeners (Baily 2005; Broughton 2002). Hasni and Matoub, like outspoken and politically engaged musicians around the globe, found themselves threatened with violence as both controversial public figures and as Algerian citizens in their own right. Their music and public image, mediated through the media, cultural industries and their audiences, became symbolic of protest, even when this was not their intention as artists. Therefore, whilst examining popular music within the socio-political conditions of $1990 \mathrm{~s}$ Algeria, this article also addresses the broader issues of political censorship and violence that have been faced by popular musicians around the world.

\section{Historical context}

Algeria was a French colony between 1830 and 1962, and only gained autonomy after a bloody eight-year war of independence. During the colonial period, nonFrench citizens, and particularly the country's Muslim majority, were increasingly marginalised, and the authorities strove to deny and destroy the notion of a distinct Algerian cultural identity. In 1881, Algeria was pronounced an "integral part of France" and was "declared to be French in the same way as Normandy, Brittany or the Savoy" (Evans 2012a: 19). Therefore, at the heart of both the independence movement and the postcolonial state were efforts to reconstruct and assert a distinct Algerian national culture. In an attempt to rid the country of French influence, the post-independence Algerian government instigated processes of Arabization, which were intended to promote the Arabic language and culture. The difficulty with Arabization was that it failed to address Algerian cultural, religious and linguistic diversity, and the country's large Berber population, in particular, believed that Arabization was intended to suppress their distinct identity.

When, in March 1980, the writer and poet Mouloud Mammeri was banned from speaking about Berber culture and language at the University of Tizi Ouzou, in the capital of the Berber region of Kabylia, "incensed students took over the campus, and the Algerian state responded with overwhelming violence" (Le Sueur 2010: 30). Protestors confronted the security forces, and the ensuing clashes led to the deaths of thirty-six Kabyle citizens. The violence that spread throughout Kabylia, in what came to be known as the Tafsut Imazighen (Berber Spring), provided the first major challenge to the Algerian government, and gave rise to politicised groups such as the Mouvement Culturel Berbère (MCB). Whilst some 
scholars have questioned the veracity of a distinct Berber history and culture, the Tafsut made the "Berber question" a central concern within national political discourse, and provided Algeria's Berber population with a public platform on which to voice their concerns (Roberts 2003: 140-150; Evans and Phillips 2007: 122-124). One of the repercussions of the violence witnessed during the Tafsut, Paul A. Silverstein (2003: 92) argues, is that it produced martyrs for the Kabyle cause, and that their deaths "squarely indexed the Kabyle political struggle against the Algerian state. The annual commemorations of Tafsut generally begin with a moment of silence for those fallen in 1980, as well as for Kabyles who have died since at the hands of the state or Islamist forces". ${ }^{1}$

Martyrdom and death have also been central to the narrative of the war of independence that the government has promoted throughout the postcolonial period, which connects the sacrifices of Algerians during the war with the suffering of the country's citizens under French rule. Martin Evans (2012a: 335) notes that estimates of the number of Algerians killed during the war varied from one to two million, and he writes that immediately following independence,

These figures became embedded in popular and official mythology,
fashioning an image of an Algerian resistance which, it was declared, had
begun in 1830 and where all the Algerian casualties were victims of French
colonialism: an epic resistance narrative that, by linking the dead and the
living into one seamless continuum, formed the basis of a post-independence
identity.

In October 1988, angry Algerian youths took to the streets of central Algiers to protest against high unemployment and social inequality. Over a period of five days, 500 people were killed in clashes with the security forces in what came to be known as "Black October". Evans (ibid: 355) argues that this violence occurred, at least in part, because "the younger generation was instinctively suspicious of the 'one million martyrs' narrative. This narrative was seen to be spurious and indiscriminate, the measure of a secretive system which justified the status quo by blaming all of Algeria's ill on the colonial past". Here, Evans reveals another trope of contemporary Algerian history and politics: suspicion, resulting from the complexities of the violence experienced by successive generations of Algerians.

In 1991, the Islamist political party the Front Islamique du Salut (FIS) won a landslide victory in the first round of the Algerian general election. A month later, in January 1992, the second round of the election was cancelled, and a coup d'état brought Algeria under military control. Efforts to suppress the Islamist opposition were increasingly met with counter-violence, including the assassination of Mohamed Boudiaf, the respected head of state and hero of the war of independence. The FIS was banned in March 1992, but this only served to strengthen the Groupe Islamique Armé (GIA), a collection of armed and increasingly violent Islamist groups, whose clashes with government forces would dominate the Algerian political landscape over the following decade. Artists and intellectuals were caught in the middle, willing to neither support a nondemocratic military government, nor an Islamist movement who considered democracy to be incompatible with their religious beliefs (Le Sueur 2010). 
This bifurcation of 1990s Algerian politics into a clash between the government and Islamists is, I acknowledge, an over-simplification, and fails to adequately address the complexities of the country's political situation during this period. Similarly, the notion of a single unified Berber movement is highly schematic, ignoring the disagreements and conflicts between various Kabyle groups (Silverstein 2003: 96). However, this article is too brief to unpack such an elaborate political picture, and I will therefore employ these three broad political positions in the subsequent discussion, whilst occasionally drawing out some of the intricacies and frictions that they embodied.

\section{Cheb Hasni}

Hasni Chakroun, who would later add the moniker "cheb" to his name, was born in 1968 in a working-class neighbourhood of Oran (Wahran), a vibrant and culturally diverse city on Algeria's northwestern Mediterranean coastline. ${ }^{2}$ Raï music developed in Oran and the surrounding regions from the late nineteenth century onwards, as a result of migration into the city from rural areas, and emerged from the integration of urban and rural musical styles. By the 1920s, raï was established as a form of popular and risqué entertainment, voicing the marginal position of its listeners through lyrics sung in the local vernacular language (Daoudi and Miliani 1996; Marranci 2005; Mehdid 2006). The young Hasni was a gifted student and keen footballer, but was drawn to music, and began his career by performing at local weddings. ${ }^{3}$ He was quickly identified as a talented singer, and invited to perform at renowned local venue La Guinguette, which had hosted many of Oran's most famous raï musicians, and this brought him a degree of fame within the local music scene. The song that launched Hasni's commercial career, and established him as one of the most prominent raï singers of the time, was "Baraka", ${ }^{4}$ recorded with acclaimed female star Cheba Zahouania in a recording studio in Oran and released in 1987. "Baraka" was sold on pirated cassettes across the country, quickly becoming a hit throughout Algeria and with the Algerian diaspora living in France (Daoudi and Miliani 1996: 104106).

Whilst fame offered the opportunity for commercial success and celebrity amongst Algerian and other North African audiences, Hasni also knew that his status as a raï singer would put him into a delicate position. He might be popular with the country's youth, but would also be marginalised from mainstream society, facing criticism from Algeria's educated middle classes, who did not value raï music, and from an increasingly prominent conservative Islamist movement. A government ban on the broadcasting of raï had only been lifted in 1985, whilst the collapse of international oil prices the following year had plunged Algeria into financial crisis, and had destabilised the domestic political situation (Le Sueur 2010: xiii). ${ }^{5}$

The lyrical themes of raï music, discussing sexuality and alcohol consumption, certainly did not fit with the government's desire to project an image of Algeria as a modern, respectable nation. Whilst the authorities were keen to promote andalus and other "traditional" musics, raï was commonly associated with bars and brothels, and the music's "syncretism did not fit at all into official national 
politics" (Schade-Poulsen 1999: 20). Raï was no more palatable for Islamists, and Mehdid, writing about "Baraka", notes that "on hearing the lyrics of this song blasted from the loud sound systems used by record shops, some Islamists requested from the shop-owners that they lower the volume, a rather exceptional gesture at the time" (2006: 209). It is not difficult to understand why the song's lyrics caused offense. In one oft-quoted passage, Hasni sings about "making love in a dirty old shack. I had her [...] because when you're drunk that's the sort of idea that runs through your head!" Yet whilst the song was undoubtedly intended to shock listeners, and embodied a sense of rebellion for Algeria's youth, Hasni was also voicing the frustrations of a younger generation, who were denied many social freedoms, faced growing unemployment and poverty, and were watching their country slide towards civil war (Virolle 1995: 72). "Baraka" therefore provided a decisive moment at which young Algerians felt able to divorce themselves from a constrained, polarised national politics, and as Mehdid (2006: 209) writes,

As the uproar about the song and the debates that ensued captured some of the rampant anti-raï feeling still persistent in society, they also revealed the depth of underlying tensions. Therefore, it seems that the song marked a politico-cultural turn while, at the same time, it pinpointed a significant moment of fracture.

Much of Hasni's musical output was concerned with love and romance, and he became known as a leading singer of raï sentimental (sentimental rai), but he nevertheless, occasionally, engaged with political subjects. For example, in his 1990 hit record "El Visa" (The Visa) he sings frankly of the frustrations of feeling trapped in Algeria;

I was going to go and see my baby

But you've taken my visa

You want to kill me!

I'm going drink myself stupid and smash everything.

Through these lyrics, speaking of feelings of anger and violence and of a desire to leave Algeria, Hasni provided a challenge to both the authorities and the Islamists. It was through his music, and that of his contemporaries, that such controversial topics could be addressed publicly. In a context of social and political turmoil, raï lyrics provided a rare space within which issues of the heart could be voiced alongside socio-political concerns, reassuring individual listeners that their worries were shared across the country. As Algerian society became increasingly fractured and shaped by opposing political positions, raï provided an alternative space for its listeners, and Schade-Poulsen (1999: 194) concludes that,

Low culture versus high culture, purity versus impurity, Islam versus the West, and youth versus experience were mediating words that transformed the game into a debate in which the leisure activities associated with raï were perceived as possibly changing or defying the power relations that were constantly negotiated and fought over in Algeria. The young, as the main consumers of raï, stood at the centre of this debate. 
As raï gained greater popularity in the early 1990s, both domestically and internationally, Hasni established himself as one of the genre's biggest stars, producing over 100 recordings during his career, and selling in excess of 400,000 cassettes by 1991 (Evans and Phillips 2007: 112). His contemporaries, Cheb Khaled and Cheb Mami, had migrated to France in the mid-1980s, in the hopes of finding commercial success, and in order to escape the growing social tensions in their country. Hasni, however, stayed in Algeria, despite the unmistakable danger for musicians and artists, who increasing faced public denunciation from the Islamists. This ensured that he remained in touch with the social and political dissatisfaction being voiced on the streets of Algerian cities and towns, and was able to offer his listeners an alternative to the violence and destruction of daily life. Whilst raï remained intolerable to most Islamists, the authorities gradually recognised the power and influence of the music upon Algeria's youth, as well as its commercial potential within international markets. The government would never fully embrace raï, or its singers, and distanced itself from the messages found in the music's lyrics, but began to programme official events that featured raï. It was therefore somewhat ironic that Hasni's final public performance was at a state-sponsored event in Algiers in July 1993, which celebrated the thirty-first anniversary of national independence, and was attended by an estimated 150,000 fans.

On 29 September 1994, Hasni Chakroun was shot and killed near to his parents' house in the Gambetta district of Oran whilst socialising with friends on his way home from a recording session. According to reports, Hasni mistook his assassin for a fan, and was gunned down in the street before his killer fled the scene. The threats that had been made against him and his family by militant Islamist groups linked to the GIA were widely known, and they were immediately accused of carrying out the assassination (Daoudi and Miliani 1996: 11).

Whilst thousands attended Hasni's funeral, others took to the streets in protest, simultaneously expressing their grief and anger at the continuing violence in their country, and demanding a free and democratic Algeria. Le Sueur (2010: 185) recalls the scale of the protests, reporting that "following his death, there were riots in Paris and at his funeral in Oran, over 10,000 people gathered in the streets". The fury of the protestors was directed towards both sides of Algeria's political divide. They were incensed that Islamists had killed such a popular public figure, and also angry at the authorities for failing to maintain the peace and protect Hasni. The impact that Hasni's death had upon Algerians should not be underestimated. Cheb Khaled, rai's most famous star, was living in Paris at the time, and stated publicly that "people lived there [in Algeria] in terror and sadness [...] they had Hasni to help them forget" (quoted in Le Sueur 2010: 185). Marie Virolle (1995: 67) argues that Hasni's assassins could not have failed to understand the consequences of their actions, and the effect that this would have upon Algeria's youth, and wrote in the months following his death that,

The killers and the people behind them were not mistaken: to attack the song, to attack the singer, is a sure way of affecting the hearts and minds of millions of people, especially the young, for whom the expressive world comes in the form above all of sung poems and music, against an overall background of a 
cultural wasteland. To kill cheb Hasni is to kill the love song and to kill the romantic expression brought by his performances.

\section{Lounès Matoub}

There can be little doubt that Cheb Hasni's assassination shocked Algerians, both domestically and throughout the diaspora. The use of violence against prominent musicians was not, however, without precedent. Only four days before Hasni's death, the renowned and outspoken Berber singer and political spokesperson, Lounès Matoub, had been abducted by members of the Islamist GIA. Matoub was a long-term pariah of both the establishment and Islamists, having openly condemned government policy and political corruption, espoused his secularist views, and insisted upon recognition of a distinct Berber cultural identity. Whilst his targeting by the GIA had therefore been of little surprise, there was still widespread condemnation of his kidnapping, particularly in Kabylia. More surprising was Matoub's release, unharmed, a fortnight later, apparently the result of the public anger directed at the GIA when 100,000 people protested in the streets of Kabyle towns and cities. In his memoires, written the following year and entitled Rebelle ("Rebel"; Matoub 1995), Matoub insisted that during his internment he had maintained little hope of ever being released alive.

Matoub was born in the small Kabyle village of Taourirt Moussa in 1956, at the height of the war of independence, and grew up in a rapidly changing Algeria. His school days coincided with the government's efforts to instigate processes of Arabization across the country, and he and his classmates were banned from speaking the local Berber language, with Berber culture and history absent from the curriculum. Like Hasni, he was drawn to music at a young age, writing songs and building his own instruments. His childhood in Kabylia was shaped by the local traditions of oral poetry and music, and his mother "possessed a treasure trove of rich and evocative words with which to depict the world" (Morgan 2004: 112).

His political consciousness and fierce pride in his Berber identity evolved during his formative years. Although he would later criticise the focus of the Algerian education system on Arabic language and history, he completed his schooling in 1975 and went on to fulfil his compulsory national service in the Algerian army, but was ridiculed by his fellow soldiers for voicing pro-Berber views and refusing to speak Arabic. After leaving the army, he returned to Kabylia, where he continued to write and perform music with the aid of his father who bought him a mandole. ${ }^{6}$ After his experiences in the army, Matoub became increasingly disillusioned with Algeria and often found himself in trouble with the authorities. On one occasion he was arrested for attacking a man with a razor blade (Morgan 2004: 115). Having decided that Algeria had nothing left to offer, he emigrated to France, arriving in 1975 to discover a large Algerian Berber diaspora that could provide performance opportunities and an audience for his music. The songs that he wrote, sung in the Berber language, drew upon a number of musical influences, and in particular from Algerian chaabi music. Matoub's break came when he met and gained the support of Idir, the revered Algerian Berber popular singer, whose hit "A Vava Inouva" ("From My Father To 
$\left.M^{\prime \prime}\right)$, released in 1976, gained unprecedented success for a song by a Kabyle musician, and took the music of the region to a wider mainstream audience. With the support of Idir, and other prominent members of the Parisian Berber community, Matoub recorded and released his debut album, Ay Izem (The Lion) in 1978, which proved widely popular and signalled the beginnings of his commercial career.

Unlike Hasni, Matoub had always explicitly aired his political views, disputing the government's vision of Algeria as a unified Arab nation and demanding recognition of Berber culture. His rise to fame coincided with the growing civil unrest in Kabylia that followed the Tafsut, ensuring that he became a figurehead and spokesperson for the country's Berber population. He was not universally acclaimed however, and his critics denounced him for a perceived overwillingness to engage in political causes: promoting Berber culture, defying the Algerian authorities, criticising the Islamist opposition, and fighting for the rights of North Africans in France. Other detractors argued that Matoub took his proBerber views too far, advancing an idealised view of Berber history and culture that led him to voice anti-Arab statements. However, Matoub ignored his critics and was unerring in his political proclamations, arguing that "when I started, modern songs didn't carry that need to express anger. They didn't have any convincing protest lyrics. I shouted out my anger in my songs. Music is my anger" (quoted in Morgan 2004: 116).

Although Cheb Hasni antagonised both sides of Algeria's political divide, Lounès Matoub was far more brazen in publicly provoking both the government and Islamists. His lyrics, unlike Hasni's, were candid in their criticisms and required little interpretation. Perhaps his most defiant song was "Tabratt I Lehkam" ("Letter to the Authorities"), which was a parody of Algeria's national anthem "Kassaman" ("We Pledge"). Although the album containing the song was only released posthumously, it typifies the political views found in his lyrics, and stands as testament to his desire to engage with controversial topics. Adapting the national anthem in order to criticise his government was inevitably a provocative move, but was considered even more outrageous because of the history of "Kassaman". The Algerian poet and writer Moufdi Zakaria had written the lyrics to "Kassaman", which rail against the French colonial authorities, during his imprisonment in the 1950s at the height of the war of independence. According to legend, Zakaria had composed them on the walls of his prison cell in his own blood (Algérie Presse Service 2012). It became a particularly potent song for the FLN during the war of independence, and was quickly adopted as Algeria's national anthem after independence (Branche 2011: 432). Matoub's satirising of "Kassaman" therefore not only defied ideas of Algerian nationalism, but also disputed the government's propagated history of a glorious, unified Algerian revolution against colonialism. In "Tabratt I Lehkam", Matoub sings that,

The cuts are made by the hand of injustice, a harvest of wrongdoing,

They tarnished the faces of our ancestors; See, he is unclean, rancid,

They grafted the image of religion and Pan-Arabism onto the face of Algeria,

Treason, treason, treason! 
Matoub's controversial lyrics and emotive public proclamations ensured that he remained in constant danger when in Algeria. During a visit to Kabylia in October 1988, he participated in a rally to support a strike by local workers. As he drove away from the march, members of the local police pulled his car over at the side of the road. The details of what followed remain unclear and disputed, but it appears that Matoub was handcuffed, before being shot five times by a police officer (Morgan 2004: 119). Somehow he survived the shooting, and photographs show him recovering in bed in a local hospital. The effects of the shooting would continue to physically impede Matoub for the rest of his life, but his status as a hero and spokesperson for the Berbers of Kabylia was only further reinforced, and Morgan (ibid: 120) writes that,

Those five bullets exalted his reputation, turning him from a popular singer with a big mouth into an existential hero, a man who had danced cheek to cheek with death, and whose words thereafter carried special magnetism and power. As murder and violence became daily facts of Algerian life, Matoub was the one singer who could speak of its horrors from direct personal experience.

As his celebrity status increased in the wake of the shooting, Matoub's declarations became more fervent, and he was provided with opportunities in Europe to publicly share his critical views of the situation in his homeland. Appearances on mainstream public television in France and Italy followed, as did a Prix de la Mémoire, awarded by Danielle Mitterrand, wife of the French President, which was bestowed upon him in 1994 for addressing Algerian political issues within his lyrics. ${ }^{7}$

It was clear to everyone that Matoub was in considerable danger: the police had left him for dead at the side of the road in 1988, and after his abduction in 1994, the GIA had condemned him to death before releasing him. If Cheb Hasni could be shot on the streets of Oran, then a figure as controversial as Lounès Matoub would always remain at risk. Violence continued to dominate Algerian society throughout the 1990s, as did the killings of public figures, including musicians and other artists. In 1995, the music producer Rachid Baba-Ahmed, one of the central figures in the development of a commercial raï sound, was shot and killed in Oran, in an assassination chillingly similar to that of Hasni.

On 25 June 1998, Matoub was driving through the mountains of his native Kabylia when his car was stopped at another roadblock. As the car came to a halt, and before anyone could get out, those manning the roadblock opened fire, riddling the vehicle with bullets that killed Matoub and injured his wife and her two sisters. His body was taken to the hospital in the nearby city of Tizi Ouzou, the capital of Kabylia, from where word of his assassination began to spread. Almost immediately, people took to the streets in angry, politically charged protest, mirroring the scenes that had followed Hasni's killing four years previously. Paul Silverstein (1998: 3) recalls the immediate impact of Matoub's death, with thousands of protestors crowding around the hospital in Tizi-Ouzou "yelling anti-government slogans - 'Pouvoir, Assassin (Government, Assassins) the crowd clearly laid the blame for Matoub's death at the state's feet". In the 
ensuing riots, government buildings were attacked and three local young men were shot by the police forces.

The outrage of the protestors was palpable, as was their condemnation of the government. However, unlike with the protests following Hasni's death, it was unclear whom the crowds on the streets blamed for the assassination. Was their anger towards the government once again due to an inability to keep the peace and protect Algerian citizens, or were the authorities being accused of something more sinister? The GIA instantly claimed responsibility for the assassination, but whilst the government supported this version of events, they failed to deflect attention from the public debates about who was culpable for killing Matoub, or to halt the sense of anger being played out in the streets.

\section{Legacies of suspicion: Who killed Hasni and Matoub?}

The endurance of shared public conspiracy theories, focused upon uncertainties about who was involved in the deaths of Matoub and Hasni, are part of broader discourse of suspicion that grew out of the turbulence of 1990s Algeria, and which has shaped subsequent Algerian socio-political debates. Conspiracy theories in Algeria have become a way of dissenting from the dominant political narrative and challenging the authorities, whilst also enabling people to enter into local, national and transnational political dialogues. Silverstein (2002: 644-645) suggests that conspiracy theories offer Algerians a form of collective unity, and writes that,

\footnotetext{
Practices of conspiracy theorizing constitute as much an element in the enactment of conflict as a response to it. Conspiracy theorizing provides a means for Algerians worldwide to construct a transnational imagined community of political engagement, outlining a common Algerian political culture across a society multiply fractured along ethnic, linguistic, and ideological dimensions.
}

Despite the suspicions surrounding the deaths of both Hasni and Matoub, their respective places within these debates are markedly different. At the time of Hasni's death, public opinion blamed the GIA, with criticism of the government focused upon their inability to protect Algerian citizens. Gradually, however, observers suggested that the killing of Hasni had benefits for the authorities, by simultaneously removing a critic of social conditions in Algeria, and stirring up public anger and resentment at the Islamists. Whilst few commentators have publicly accused the government, enduring widespread suspicions around Hasni's assassination have never fully disappeared. In November 1994, government security forces announced that they had killed Saadane Ameur, a suspected Islamist militant who they had linked to the murders of Hasni and other prominent public figures (Associated Press 1994). Yet there was little evidence of a thorough investigation or of Ameur's guilt, and the sense that the case remains unresolved has served to fuel the suspicions that continue to surround Hasni's assassination.

In the case of Matoub's death, conspiracy theories emerged almost instantaneously and were voiced during the protests that immediately followed his killing. Silverstein (2002: 644), who was conducting ethnographic research in 
Paris at the time of Matoub's assassination, recalls a conversation with an Algerian friend Akli, who "rehearses the political logic of a number of possible alternative scenarios-the government wanting to eliminate a thorn in its side; Kabyle militants wanting to create a martyr-before espousing a conspiracy between military and Islamist forces". Such suspicions were commonplace at the time, and persist in discussions of both Matoub's death and of the politics of 1990s Algeria (Morgan 2004: 126).

A number of commentators have speculated about governmental and military involvement in the assassination, mirroring many of the claims made about Hasni's death. The authorities, it is suggested, hoped to generate public anger against the Islamists by killing Matoub and laying the blame upon the GIA, both removing a dissenting public voice and provoking public outrage towards their opponents. Others have noted that Matoub was shot only a few days before the introduction of new Arabization legislation, of which he would almost undoubtedly have been a vocal critic. The French television channel Canal+ aired a documentary in 2000 that challenged the official account of his death, and featured interviews with Matoub's friends and family, alongside the views of political commentators, in which the government was accused of involvement in his killing.

In July 2011, Malik Madjnoun and Abdelhakim Chenoui were convicted of Matoub's killing. Whereas the death of Hasni's accused killer had produced a prevailing sense of suspicion, the trials of Madjnoun and Chenoui provoked public uproar. During the hearing, the courtroom descended into chaos as Matoub's mother and sister led chants of "free Madjnoun and Chenoui! Find the real perpetrators!" The trial was temporarily suspended when Matoub's sister beseeched the judge that the accused had "nothing to do with the case". A press report on the Al Arabiya news network revealed the sense of confusion surrounding the trial, and noted that "Matoub's widow Nadia has blamed the Armed Islamic Group (GIA) for Matoub's death but his sister and mother believed there were other possibilities including a politically motivated killing" (Ajbaili 2011). The comments section below the report was filled with the views of readers arguing about the truth behind Matoub's death and the possibility of the authorities being implicated in his assassination (ibid).

The memorialisation and mythologisation of these two musicians, whose names have become synonymous with the violence of 1990s Algeria, are kept alive through the recordings that they made during their lives. There have been numerous posthumous reissues and compilations of their music, both official and unofficial, which remain popular with Algerian listeners. However, the Internet has become the primary site for preserving collective memories and conspiracy theories about Hasni and Matoub. In the case of Hasni, this consists of websites that celebrate his musical legacy, alongside the occasional journalistic article that mourns his loss. ${ }^{8}$ The raï songs that he recorded are part of the collective memory of Hasni and the music's popularity in the 1990s, and his legacy adheres to the romanticised notion of the premature death of the musician. In contrast, the Internet content about Matoub is far more politicised, and focuses upon his contribution to the Berber political cause, and to the anger surrounding the circumstances of his death. On websites that celebrate and mythologise him, Matoub is presented as a spokesperson for Algerian Berbers. His disputes with 
other high-profile Kabyle musicians are conspicuously absent from this narrative, reinforcing the notion of him as a spokesperson for a collective Kabyle public. Whilst it is not difficult to find audio and video files of Matoub's recordings and live performances, the online discourse amongst his fans often focuses more upon his political activism and the circumstances of his death, rather than upon his music. ${ }^{9}$

The video and audio files of Hasni and Matoub that are hosted on websites and social media provide a salient space within which memories and conspiracy theories circulate, connecting individuals in Algeria with a transnational diasporic network. High quality film clips of their live performances, often originally broadcast on television networks, appear alongside media produced by fans that combine their recordings with images of the musicians, transcriptions of their lyrics (in various languages), and political messages. The comments sections below videos on social media such as YouTube are often filled with nostalgic memories of their lives, whilst also offering a place within which debates about their killings can be played out.

The enduring controversies about the killings of these two musicians form an important part of Algerian public political discourse. Algerians continue to celebrate Hasni as a talented singer whose life was tragically cut short by violence, whilst Matoub is remembered as a political spokesperson and activist whose music continues to engage with the problematic issues of Berber rights and cultural recognition in the country. Although contemporary political debates have expanded beyond the violence of this period of Algerian history, the shared, collective memories of Hasni and Matoub's deaths offer potent symbolic reminders of the socio-political problems that Algeria has faced, and which, in many cases, remain unresolved to this day.

\section{Conclusions}

Whilst a number of high profile public figures were killed in Algeria during the 1990s, it is the lives and deaths of Hasni and Matoub that remain at the forefront of collective memories of the violence of this period. Music is a particularly valued and cherished part of Algerian culture, and both musicians were widely revered during their lifetimes. Although other artists, writers and politicians were also victims of the Algerian civil war, it is perhaps the physical remnants of their lives, in the shape of recordings and films of their performances, that ensure Hasni and Matoub remain so accessible and important to contemporary audiences. These recordings circulate amongst listeners on the Internet, and open up their music to a younger listenership. Their lyrics employ the everyday language used by many Algerians, voicing the frustrations of their audiences during a period of extreme socio-political turmoil. They also embody the idea of the musical prodigy whose career is tragically cut short in their prime (epitomised, within a nonAlgerian context, by musicians such as Jimi Hendrix, John Lennon, and Jim Morrison), and this continues to generate the public sorrow that pervades collective memories of them. The conspiracy theories that surround their killings serve to further reinforce this sense of tragedy, whilst also enabling Algerians to 
engage with socio-political discourse through enduring critical suspicion of politicians in positions of power.

Although Algeria has not experienced the same recent levels of violence and political unrest as its neighbours in the North African and Arab world, the country remains volatile and public protests are not uncommon. In early 2011, the first wave of protests in the "Arab Spring" included violence in Algeria, with cases of self-immolation and clashes between protestors and security forces on the streets of Algerian cities. At the same time, Kabyles continued to publicly remonstrate against the government. On 1 February 2011, 15,000 university students protested in Tizi Ouzou, challenging President Bouteflika and his government (Jijel 2012). A journalist, reporting live from the scene via the Internet, described the situation thus:

Tizi Ouzou, 10.30. The Hasnaou University campus is abuzz. From speakers installed in front of the Central Library, the voice of the singer Lounès Matoub, murdered on the $25^{\text {th }}$ June 1998 , did not stop recalling the fight for democracy, Tamazight and for human rights. (ibid)

This shows that more than a decade after his death, the music of Matoub continues to signify a sense of political dissention, and still plays a role in contemporary protests, particularly in Kabylia. The music of Hasni, in contrast, forms part of a body of works that symbolise the commercial successes and international fame of Algerian raï music in the 1990s, whilst simultaneously evoking the political instability of the country during this period. ${ }^{10}$ Despite the differences between their personalities and their music, there remains a profound connection between Hasni and Matoub, both as victims of the same conflict, and as musicians who were able to reflect the frustrations and anger of many Algerians at this time. The collective memories of their lives and deaths are therefore an enduring part of socio-political discourse, and highlight the ability of Algerian musicians to connect directly with their listeners in a way that continues to evade many of those involved in the country's politics.

In 2009, the revered Berber musician Idir, who had been Matoub's mentor in Paris, was interviewed about the relationship between Berber music and politics. When asked about Matoub's death, and the suspicions about governmental involvement in his killing, Idir responded by stating that,

In our culture poets have more power than politicians. That stems from the fact that our culture is one of oral tradition. 200 years ago, you would find that when two tribes went to war, each side had its poet, and the poets fought with words. The one who could throw out the most beautiful word won, and the war would end, because the word is above economics, politics, business, etc. Poets have a position of choice in our society. (Afropop Worldwide 2011)

The careers, deaths and enduring legacies of Cheb Hasni and Lounès Matoub illustrate how, as musicians who achieved fame and respect in their own culture, they were afforded a space within which to engage with national politics, and open up socio-political discourse to their listeners through their music and lyrics. Their killings underline the tragic situation in Algeria at the time, when, as with 
Ahmad Zahir in Afghanistan, the critical voices of musicians were met with acts of violence and death. Their killings provoked mourning and anger at the contentious contexts within which they died, but their enduring popularity has ensured that they have become part of an Algerian collective memory of this period of national history, and of the dangers that musicians faced in voicing their opinions. Whilst politicians from across the Algerian political spectrum are continually met with public criticism and scepticism, the legacies of Hasni and Matoub show that in contemporary Algeria, the voices of poets seem to have more power than those of politicians.

\section{Endnotes}

1 See also Judith Scheele's (2006) ethnographic work, which explores issues of memorialisation and death through a study of Kabyle graveyards.

${ }^{2}$ Mehdid (2006: 199) explains that "the term 'cheb' (feminine 'cheba') meaning 'a young person' or 'young' became a title associated mostly with raï singers in the wake of the success of their music in the early eighties".

${ }^{3}$ Whilst raï has often been marginalised within Algerian society, singers have frequently been employed to perform at weddings. Marranci (2005: 198) notes that during the early twentieth century, the cheikhs and cheikhas of Oran, who were at the heart of the development of raï, often sang at the weddings of those unable to afford the more expensive maddahat musicians.

4 "Baraka" colloquially indicates a shack or hut, which makes sense in the context of the lyric's narrative. However, it also translates as a blessing or the spiritual presence of God, as well as a more secular meaning in (North African) French, where it can indicate "wild luck", "luck" or good fortune.

${ }^{5}$ Despite the broadcasting ban on raï, lasting until 1985, Langlois (2009: 223) suggests that censorship was in effect extremely difficult, with recordings produced outside of state control, and distributed through unofficial channels, such as street corners and market stalls.

${ }^{6}$ The mandole is a fretted string instrument, related to the mandolin, and is commonly used in chaabi and other Algerian musics.

7 The Prix de la Mémoire (Memory Prize) was awarded in recognition of the work of individuals in defending human rights and free speech. Danielle Mitterand's husband, the former French President François, was a controversial figure in Algeria, having stated, as French Interior Minister during the war of independence, that "Algeria is France". Later, however, he also "legalised the foundation of immigrant non-profit associations in France, paving the way for what would become known as the 'Beur Movement'" (Silverstein, 2003: 92).

${ }^{8}$ For an example of an artist website for Cheb Hasni: MaghrebSpace 2014. For an example of a journalistic article on Hasni's legacy: Mehdi 2014.

${ }^{9}$ For example of an artist website for Lounès Matoub: Matoub Lounès n.d.

${ }^{10}$ The Rough Guide to Raï (World Music Network 2008), for example, includes Hasni's "Menghirek entia fi dounia" ("No One Matters More in My Life") alongside songs by Cheb Mami and Cheb Khaled. 


\section{References}

\section{Bibliography}

Afropop Worldwide. 2011. Berber Rising II: Malika Zara, Najat Aatabou, Idir, Takfarinas. Interviews conducted by Banning Eyre, http://www.afropop.org/wp/2520/berber-rising-ii-malika-zarra-najat-aatabouidir-takfarinas; Accessed: 8 May 2014.

Ajbaili, M. 2011. Suspected Killers of Algeria [sic] Berber Musician Lounès Matoub given 12 Years in Prison. Al Arabiya News. http://english.alarabiya.net/articles/2011/07/19/158245.html; Accessed: 7 May 2014.

Algérie Presse Service. 2012. "Kassaman", Anthem to the Glory of Algerian Revolution. https://0global.factiva.com.wam.city.ac.uk:443/redir/default.aspx?P=sa\&an=ALGPS000 20120709e8750002u\&cat=a\&ep=ASE; Accessed: 1 August 2014.

Associated Press. 1994. Presumed Killer of Popular Singer Slain With AM-FranceAlgeria-Crackdown. http://www.apnewsarchive.com/1994/Presumed-Killer-ofPopular-Singer-Slain-With-AM-France-Algeria-Crackdown/id06ea82e71960f09c496c9712aac77efa; Accessed: 7 May 2014.

Baily, J. 2005. So Near, So Far: Kabul's Music in Exile. Ethnomusicology Forum 14 (2): 213-233.

Branche, R. 2011. The Martyr's Torch: Memory and Power in Algeria. The Journal of North African Studies 16 (3): 431-443.

Daoudi, B. and Miliani, H. 1996. L'aventure du raï. Paris: Edition du Seuil.

Evans, Martin 2012a. Algeria: France's Undeclared War. Oxford: Oxford University Press. 2012b. Algeria's Jewish Question. History Today July: 10-16.

Evans, M. and Phillips, J. 2007 Algeria: Anger of the Dispossessed. New Haven and London: Yale University Press.

Horne, A. 1977. A Savage War of Peace: Algeria 1954-1962. New York: New York Review Books.

Jijel. 2011. Tizi Ouzou: 15,000 étudiants dans la rue. http://www.jijel.info/content/tizi-ouzou-15000-\%C3\%A9tudiants-dans-la-rue; Accessed: 8 May 2014.

Langlois, T. 2009. Music and Politics in North Africa. In L. Nooshin Ed. Music and the Play of Power in the Middle East, North Africa and Central Asia. Farnham: Ashgate: 207-227.

Le Sueur, J. D. 2010. Between Terror and Democracy: Algeria since 1989. London: Zed Books.

MaghrebSpace. 2014. http://www.maghrebspace.net/Music/Cheb+hasni/19328/Ec outer; Accessed: 30 November 2015.

Marranci, G. 2005. Algerian Raï into Beur Raï: The Music of Return. In D. Cooper and K. Dawe Eds. The Mediterranean in Music: Critical Perspectives, Common Concerns, Cultural Differences. Oxford: Scarecrow Press: 197-206.

Matoub Lounès. n.d. http://matoub.rebelle.free.fr/; Accessed: 4 December 2014. 
Matoub, L. 1995. Rebelle. Paris: Stock.

McDougall, J. 2005. Savage Wars? Codes of Violence in Algeria, 1830s-1990s. Third World Quarterly 26 (1): 117-131.

Mehdi, A. 2014. Hasni ressuscité à Bab El Oued. L'Expression. http://www.lexpressiondz.com/culture/203094-hasni-ressuscite-a-bab-eloued.html; Accessed: 19 November 2015.

Mehdid, M. 2006. For a Song: Censure in Algerian Rai Music. In M. Drewett and M. Cloonan Eds. Popular Music Censorship in Africa. Aldershot: Ashgate: 199214.

Morgan, A. 2004. Guerilla of Pop: Matoub Lounès and the Struggle for Berber Identity in Algeria. In M. Korpe Ed. Shoot the Singer: Music Censorship Today. London: Zed Books: 106-126.

Roberts, H. 2003. The Battlefield: Algeria 1988-2002. London and New York: Verso.

Schade-Poulsen, M. 1999. Men and Popular Music in Algeria: The Social Significance of Raï. Austin: University of Texas Press.

Scheele, J. 2006. Algerian Graveyard Stories. The Journal of the Royal Anthropological Institute 12 (4): 859-879.

Silverstein, P. A. -

1998. "The Rebel is Dead. Long Live the Martyr": Kabyle Mobilization and the Assassination of Lounès Matoub. Middle East Report, 208: 3-4.

2002. An Excess of Truth: Violence, Conspiracy Theorizing and the Algerian Civil War, Anthropological Quarterly 75 (4): 643-674.

2003. Martyrs and Patriots: Ethnic, National and Transnational Dimensions in Kabyle Politics. In J. McDougall Ed. Nation, Society and Culture in North Africa. Abingdon: Routledge: 87-111.

Virolle, M. 1995. La Chanson Raï: De L'Algérie Profonde à la Scène Internationale. Paris: Karthala.

\section{Discography}

Cheb Hasni. 1987. Baraka, Recording label unknown.

Idir. 1976. A Vava Inouva, EMI Pathé.

Lounès Matoub -

1978. Ay Izem, D.S. Azwaw.

1998. Lettre Ouverte Aux, Blue Silver.

The Rough Guide to Raï. 2008. World Music Network.

\section{Videography}

Breaking the Silence. Music in Afghanistan. 2002. Director: Simon Broughton. Songlines Films/MWTV (UK).

Lounés Matoub: Le Grand Manip. 2000. Canal+ (France). Broadcast: 31 October 2000. 